D) Check for updates

Cite this as: BMJ 2021;372:n176 http://dx.doi.org/10.1136/bmj.n176

Published: 03 February 2021

\section{How Joe Biden plans to heal American healthcare}

In this Feature article (BMJ 2021;372:n142, doi:, published 19 January 2021) Don Berwick was described as "former acting head of Medicare and Medicaid." He was in fact head of Medicare and Medicaid. This has been corrected. 